九州大学学術情報リポジトリ

Kyushu University Institutional Repository

\title{
Cretaceous-Tertiary Unconformity in Nagashima, Southwest Kyushu
}

Takai, Yasuaki

Geological Survey of Japan

Matsumoto, Tatsuro

Faculty of Sciences, Kyushu University

https://doi.org/10.5109/1526195

出版情報：九州大學理學部紀要：Series D, Geology. 11 (2)，pp.257-278，1961-11-15. Faculty of Science, Kyushu University バージョン：

権利関係 : 
Mem. Fac. Sci., Kyushu Univ., Ser. D, Geology, Vol. XI, No. 2, pp. 257-278, text-figs. $1-4$, pls. 11-12, November 15, 1961

\title{
Cretaceous-Tertiary Unconformity in Nagashima, Southwest Kyushu*
}

\author{
$\mathrm{By}$
}

\author{
Yasuaki TAKAI** and Tatsuro Matsumoto
}

\begin{abstract}
A distinct unconformity is recognized between the Cretaceous and Tertiary rocks in Nagashima and vicinities (Kagoshima Prefecture) in the coastal region of southwest Kyushu. The Tertiary rocks are referred to the Akasaki formation and the overlying Nummulites beds. The basal red-beds rest on the Cretaceous Himenoura and Goshonoura groups with an angular structural unconformity. The Cretaceous sequence below the unconformity ranges from the zone of Inoceramus balticus (Campanian), through that of Inoceramus uwajimensis (Coniacian), to the probably Turonian Upper Goshonoura. From the observed facts and other available evidence comments are given on more general geological problems.
\end{abstract}

\section{Introduction}

The problem of the Cretaceous-Tertiary boundary in the Japanese Islands has been discussed on several occasions. On the basis of evidence provided by NAGAO (1924, 1925), Imai (1924), Yabe and Shimizu (1924a), Tokunaga (1923), etc., YABE (1927) comprehensively summarized the stratigraphical relations actually observed in various areas in the Japanese Islands. His proposal of the problem was quite international, but the evidence available at that date was not enough for the solution of the problem.

About a decade later the stratigraphic relations of the Cretaceous and Tertiary rocks were again discussed by OTUKA $(1935,1939)$ and KoBAyASHI $(1937,1941)$. The discussion on this occasion was primarily from the standpoint of the tectonic history.

In connection with the international problem of the Cretaceous-Tertiary boundary once again active studies have been recently carried out by many geologists in various parts of Japan. The status of the knowledge in Japan lead from the available evidence up to 1959 has been summarized by Matsumoto (1960) on the occasion of the International Geological Congress, XXI Session, Norden. Being stimulated by a symposium held in Tokyo, 1959, research work in Japan is still in progress. Some of the results would give a contribution to the international problem of the boundary. Others may concern rather with the tectonic history of Japan. In this paper the basic facts in local geology are described but an attempt is extended for some general problems.

* Received June 15, 1961.

** Geological Survey of Japan. 


\section{Geological Observation in Nagashima}

1. Geological outline.-Nagashima is an island situated at the gorge of the gulf of Yatsushiro (i.e. the so-called Shiranuhi embayment), about 50 to $60 \mathrm{~km}$. southwest of Yatsushiro city. The outline of the island is rather irregular but approximately $15 \mathrm{~km}$. in length from north to south and $10 \mathrm{~km}$. in breadth from east to west.

The island is primarily occupied by the probably Pliocene andesites and associated sediments and also Quaternary welded tuff. Underneath these volcanic groups crop out the Cretaceous and Lower Tertiary rocks on the coast of the northeastern extremity of Nagashima* and adjacent smaller islands Shoura-jima ${ }^{2 *}$, Ikara-jima ${ }^{3 *}$ and still smaller islets called Kita [North] and Minami [South] Takeno-shima**. This area is located to the southwest of Shishi-jima and geologically connected to the Cretaceous and Lower Tertiary region of Amakusa, Kumamoto Prefecture, although it belongs administratively to Higashi-machi, Izumi-gun, Kagoshima Prefecture ${ }^{5 *}$.

Fig. 1 is a geological map showing the outcropping rock units in this particular area. While the Lower Tertiary beds run from northeast to southwest with gentle

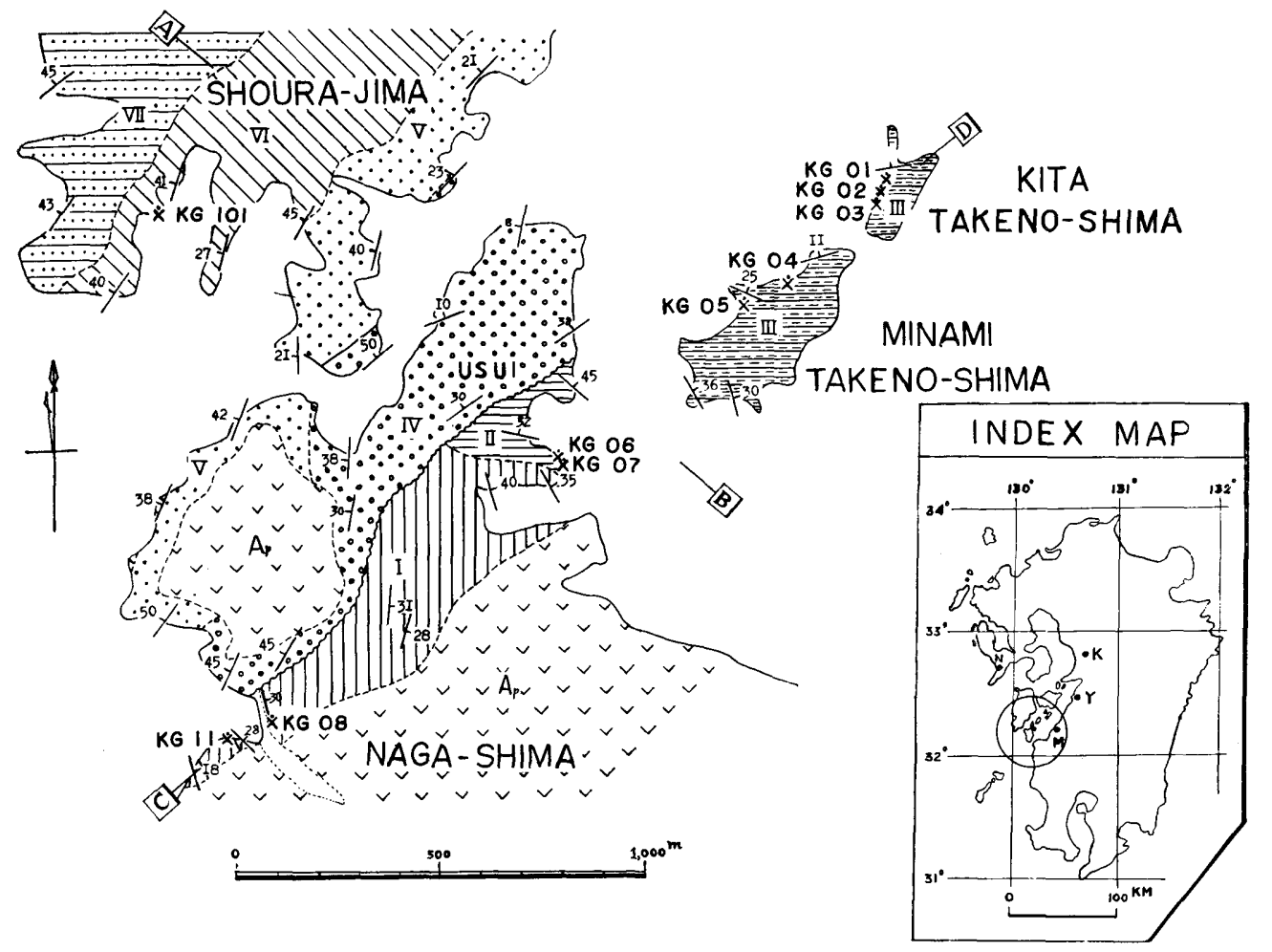

Fig. 1. Geological map of the northern Nagashima area. See Fig. 2 for the explanation of the symbols. Index map of Kyushu showing the location of the mapped area at the center of a circle and cities of Kumamoto, Yatsushiro, Minamata and Nagasaki with black spots, K, Y, M and N.

\footnotetext{
*長島, ${ }^{2 *}$ 諸浦島, ${ }^{3 *}$ 伊唐島, ${ }^{4 *}$ 北竹の島, 南竹の島, ${ }^{5 *}$ 鹿児島出水郡東町
} 
or moderate northwesterly dip, the Cretaceous beds take variable attitudes with the NW strike and northeastward dip on the average. Thus the boundary between the two groups of strata is a significant unconformity.

2. Cretaceous sequence.-In spite of the narrowness of the exposed belt between the basal unit of the Lower Tertiary group of beds and the northern margin of the volcanic group, a considerable thickness of the Cretaceous sequence can be observed. Although the exposure is here and there interrupted by the sea water and by the dense vegetation on the hill, the following ascending succession is observed from the east side of the Mifuné* inlet to the northern islet of Takeno-shima (see also a geological profile in Fig. 2).

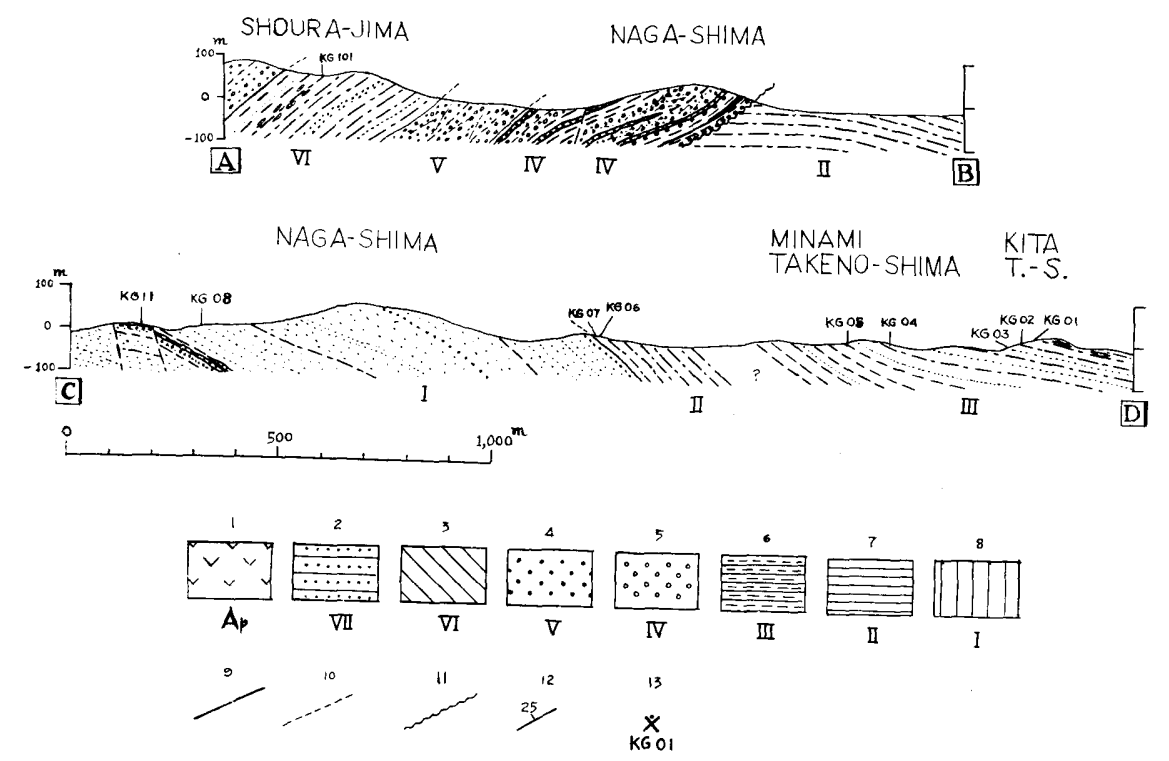

Fig. 2. Geological profiles of the northern Nagashima area along $A-B$ and C-D in Fig. 1. Explanation of symbols in Figs. 1-2: 1: Pliocene two-pyroxene andesite $[\mathrm{Ap}] ; 2,3,4$ and 5: Lower Tertiary group of beds [units VII, VI, V and IV]; 6, 7 and 8: Upper Cretaceous group of beds [units III, II and I in the text]; 9: fault; 10 : boundary of the units; 11 : unconformable boundary between the Cretaceous and Lower Tertiary group of beds; 12 : strike and dip; 13 : location of fossils.

I. Unit of sandstone, probably more than $450 \mathrm{~m}$. in thickness. Owing to the interrupted exposures the detailed description may be given as follows with lettering.

Ia. Sandstone with irregular interbeds of red to purple shale and also yellowish green shale. The sandstone exposed on the east side of the Mifuné inlet is sometimes conglomeratic and partly fossiliferous. The fossils are accumulated in patches or in lenticular beds, as seen at loc. KG 08 and KG 11. The fossiliferous layer at loc. KG 11 is stuated about $13 \mathrm{~m}$ stratigraphi- 
cally below a $2 \mathrm{~m}$. bed of red shale. The rocks in this place are so weathered that the fossils are mostly represented as casts. Preliminarily identified species are as follows:

Anomia sp.

loc. $\mathrm{KG} 08$

Astarte sp.

Corbula (Caryocorbula) higoensis (MATSUMoto)

Corbula sp.

"Cerithium" pyramidaeforme NAGAO

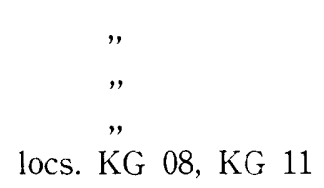

Ib. Poorly exposed part (details uncertain).

Ic. Sandstones of various grades of coarseness, exposed on the hilly part. Subrounded pebbles of siliceous rock are contained in the coarse-grained sandstone. This pebbly layer is intraformational, because fossils similar to those in Ia are found in the beds below and above it.

Id. Unexposed part.

Ie. Medium-grained sandstone, exposed on the coast of a small inlet south of Usui.* This is apparently conformable below the next unit (II). In a $3 \mathrm{~m}$. layer of dark grey shale in the sandstone a fragmentary large Inoceramus was once found by T. SUJAKU. This is about $130 \mathrm{~m}$. stratigraphically below the base of unit II.

From the stratigraphic position, sedimentary facies and fossil contents beds Ia to Ic are certainly to be assigned to the Upper formation of the Goshonoura group (NAGAO, 1925, 1930; Matsumoto, 1938, 1954 [Editor]), while Ie is probably referable to the basal part of the Himenoura group (see p. 261). The boundary of the two groups, which should be within the part represented by Id, is not exposed in the present area.

Ila. Unit of black to dark grey siltstone, somewhat fine-sandy and mostly massive, with poor development of lamination; about $150 \mathrm{~m}$. in thickness, exposed on the coast near Usui*; fossiliferous in the lower part, in which calcareous nodules are also contained, as represented by localities KG 06 and KG 07 . The fossils were obtained from the siltstone itself but not from the nodules. They are fairly numerous but more or less deformed. The identified species are
Inoceramus cf. wwajimensis YEHARA
loc. KG 07
Gaudryceras denseplicatum (JIMBO)
Kingena (?) sp.
locs. KG 06, 07
loc. $\mathrm{KG} 06$

The fossil Gaudryceras from these localities is represented by fragmentary body whorls and the septate whorls are not attached to them or at least unpreserved. A still more poorly preserved fragment (probably a part of the body whorl) of another, large indeterminable, thin shelled ammonite was obtained at loc. KG 07. Inoceramus shells are also somewhat fragmentary and accumulated in particular layers. All these features suggest the process of transportation acting during the time of deposition. Lenticular thin layers $(5-10 \mathrm{~cm}$. thick) are occasionally contained in the uppermost frac- 
tion of the exposed part of unit Ila.

IIb (?). Submarine part between the eastern coast of Nagashima and the southwestern end of Takeno-shima, which is presumably made up of softer rock such as mudstone. If no fault runs across the strait, the thickness of this part should be estimated at about $130 \mathrm{~m}$. This part may be called IIb (?), for convenience, and the underlying, exposed part IIa.

III. Unit of shale with laminae and thin layers of sandstone

IIla. Black shale predominant, with occasional sandy laminae, exposed in the southern islet of Takeno-shima. Fossil localities KG 04 and KG 05 are in the upper part of this exposed unit. The specific names have not been well determined but are suggested as follows:

Inoceramus sp., somewhat inflated and ribbed as in I. inconstans Woods or in $I$. balticus balticus BOEHM, but indeterminable because of unpreserved condition of the hinge part loc. KG 04

Gastropod indet (a small form)

A few other mollusca loc. $\mathrm{KG} 05$ loc. $\mathrm{KG} 05$

IIIb. Uniexposed part between the two islets of Takeno-shima, which probably corresponds to a slight thickness of strata.

IIIc. Black shale with layers rich in calcareous nudules and with laminae of fine-grained sandstone; fossiliferous at horizons as represented by localities KG 01-03 in Kita Takeno-shima. The identified species are

Inoceramus elegans pseudosulcatus NAGAO and MATsumoto loc. KG 01 Inoceramus sp. indet, cf. I. orientalis Sokolow locs. KG 01, KG 02

Inoceramus cf. balticus toyajoanus NAGAO and MATsumoto loc. KG 03 and there are other undetermined pelecypod and echinoid species from loc. $\mathrm{KG} 01$.

Assuming that the strata are conformable from IIIa to IIIc, the thickness of unit III is estimated at about $250 \mathrm{~m}$. From the stratigraphic sequence, lithologic characters and fossil contents, the units II and III are certainly to be assigned to the Himenoura group (NAGAO, 1922; YABE, 1927; Matsumoto, 1938; MATsumoto [Editor], 1954; UEDA and FURUKAWA, 1960), a representative of the Senonian in southwest Kyushu. The thickness of the described sequence of the group in the present area, including Ie at its base, is about $680 \mathrm{~m}$. The entire thickness would be still thicker, because the shale with fine sandy laminae which resembles the rock of unit III is exposed in the northern part of Ikara-jima.

3. Lower Tertiary sequence.-The Lower Tertiary beds have the general trend of NE-SW, gently or moderately inclining northwestward, with some modification here and there. The following ascending sequence is observable in the present area.

IV. Unit of red beds and conglomerate, about $210 \mathrm{~m}$. The basal $50 \mathrm{~m}$. is somewhat different from the main part in the intercalation of dark grey shale (for details see paragraph 4 in page 263). Approximately 80 percent of the constituents of the main part is conglomerate and pebble-bearing coarse-grained sandstone; the rest is greenish and red to purple shales. The conglomerate is 
massive, cross-laminated, with major bedding at intervals of $10 \mathrm{~m}$. or so. It is bluish grey in colour and is made up predominantly of subrounded pebbles of medium-grained sandstone and dark grey shale and subordinately of those of andesite and chert, with poor sorting. The intercalated layers of greenish grey shale ranges from 1 to $5 \mathrm{~m}$. in thickness, sometimes with sandy laminae. Thinner and irregular layers of the same rock may occur in the basal conglomerate. The red to purple shale occurs at horizons of $10,40,110,150 \mathrm{~m}$. from the base as irregular layers of 3 or $4 \mathrm{~m}$. with uneven upper and lower surfaces. No fossils are found from this unit.

This unit seems to vary greatly in thickness and in the detailed feature. For instance, it is about $120 \mathrm{~m}$. thick and has fewer red beds in the southwestern part.

V. Unit of granule-conglomerate, without red beds, about $150 \mathrm{~m}$. The majority $(80 \%)$ of the unit consists of granule-conglomerate of yellowish grey to ochre colour, with virtual bedding at intervals of 10 to $20 \mathrm{~m}$. Grey shale and muddy fine-grained sandstone, occur as single or alternating beds of 1 to $5 \mathrm{~m}$. thick. Major cross-bedding is developed, and lenticular or irregular layers (less than $2 \mathrm{~m}$.) of pebble conglomerate may be found in the granule-conglomerate. The pebbles are mostly subrounded, consisting those of chert, quartzite, sandstone, shale and rhyolite in the order of abundance. The granule-conglomerate itself is massive, better sorted than the conglomerate of unit IV, and contains abundantly granules of feldspars, quartz and chert. No fossils have been found yet.

VI. Unit of black siltstone, about $250 \mathrm{~m}$., with the following local sequence: VIa. Thin bedded alternation of black shale and fine-grained sandstone, $80 \mathrm{~m}$., showing sometimes an intraformational folding.

VIb. Medium-grained sandstone, containing sporadically pebbles of chert, $2 \mathrm{~m}$.

VIc. Black siltstone and thin bedded alternation of VIa type in composite repetition, $20 \mathrm{~m}$., with nodules and irregular small bodies $(30 \times$ several $\mathrm{cm}$.) of fine-grained sandstone. At Motoura* Nummulites sp. was once obtained by Taro KanAyA from the sandstone lens (his loc. F 5) and Trochocyathus (?) from the neighbouring loc. $\mathrm{F} 4$.

VId. Thick beds (1-6 m. each) of grey, medium-grained sandstone and thin beds $(10-30 \mathrm{~cm}$. each) of dark grey sandy shale in repetition, $20 \mathrm{~m}$., followed by thin bedded alternation of black shale and fine-grained sandstone, $20 \mathrm{~m}$.

VIe. Dark grey siltstone, $40 \mathrm{~m}$., rather massive, containing isolated, angular sand grains, lenticular sandstone and calcareous nodules in the upper part. This member is fossiliferous, as represented by localities KG 101 and 102. The species identified by A. Mizuno and partly by K. OYAma and O. FUKUDA are 
Colpospira (Acutospira) tashiroi KotakA locs. KG 101, 102

(also KOTAKA's type locality about $1000 \mathrm{~m}$. north of Mifuné)

Colpospira (Acutospira) okadai (NAGAO) KG 102

Orthaulax sp. $\quad$ KG 101

Athleta nishimura NAGAO KG 102

Pseudoneptunea (?) sp. KG 102

Venericardia cf. nipponica YoKoyama KG 102

Adamnestia (?) sp. KG 102

Ostrea sp. KG 102

coral KG 102

Planularia sp. KG 102

From the same locality (KG 102) HATAE (1960b) reported the rare occurrence of Nummulites sp. and Orthaulax japonicus NAGAO.

VIf. Black shale, with interbeds ( $1 \mathrm{~m} . \pm$ each) of fine-grained sandstone, $20 \mathrm{~m}$.

VIg. Greyish white, coarse-grained sandstone, $10 \mathrm{~m}$.

VIh. Black shale with lenses of coarse-grained sandstone, $30 \mathrm{~m}$.

VII. Unit of conglomeratic sandstone, about $250 \mathrm{~m}$. Massive, yellowish white, conglomeratic sandstone is predominant, with interbeds (each $1 \mathrm{~m}$. or thinner) of dark grey sandy shale. The pebbles are mostly well rounded, quartzose rock and rarely andesite and shale. Cross-lamination is sometimes discernible. The upper $40 \mathrm{~m}$. has more frequent interbeds of shale, forming regular alternation.

VIII. Unit of black shale, frequently alternating with fine-grained sandstone, $600 \mathrm{~m} .+$

From the superposition, lithologic characters, and the contained fossils the most reasonable assignment is as follows:

unit IV: Akasaki formation (NAGAO, 1922)

unit V: Shiratake formation (in part) (NAGAO, 1922

unit VI: Nummulites beds (YABE and Hanzawa, 1925) and the lower part of the Tanasoko formation (MATSUSHITA, 1949)

unit VII: upper part of the Tanasoko formation or the basal part of (or transitional beds to) the Kyoragi formation

unit VIII : Kyoragi formation (proper) (NAGAO, 1922)

4. Exposures of the unconformity.-There are two good exposures of the unconformity between the Cretaceous and Tertiary groups of beds. One is on the northeastern coast of Usui and the other is at the northern extremity of Ikara-jima. The description of the observed relations follows.

(1) Exposure near Usui (Fig. 3).-The plane of unconformity is well marked due to the differential erosion. So far as the exposed part is concerned, it is rather even. The Cretaceous rock below the plane is dark grey, massive, sandy siltstone with occasional, thin $\left(5-10 \mathrm{~cm}\right.$.) interbeds of fine-grained sandstone, with the attitude $\mathrm{N} 45^{\circ} \mathrm{W}$ strike, NE $45^{\circ}$ dip. It represents a part of unit Ila in the above description. The basal conglomerate of the Lower Teritary above the unconformity plane is dark grey, 


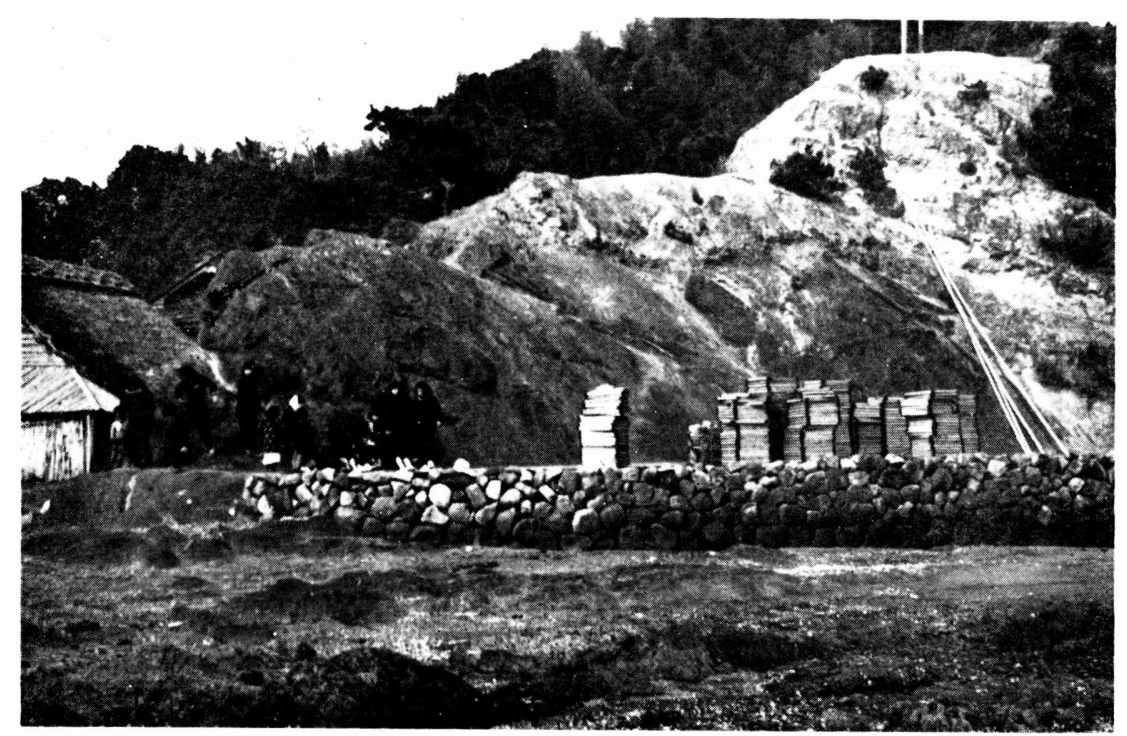

a.

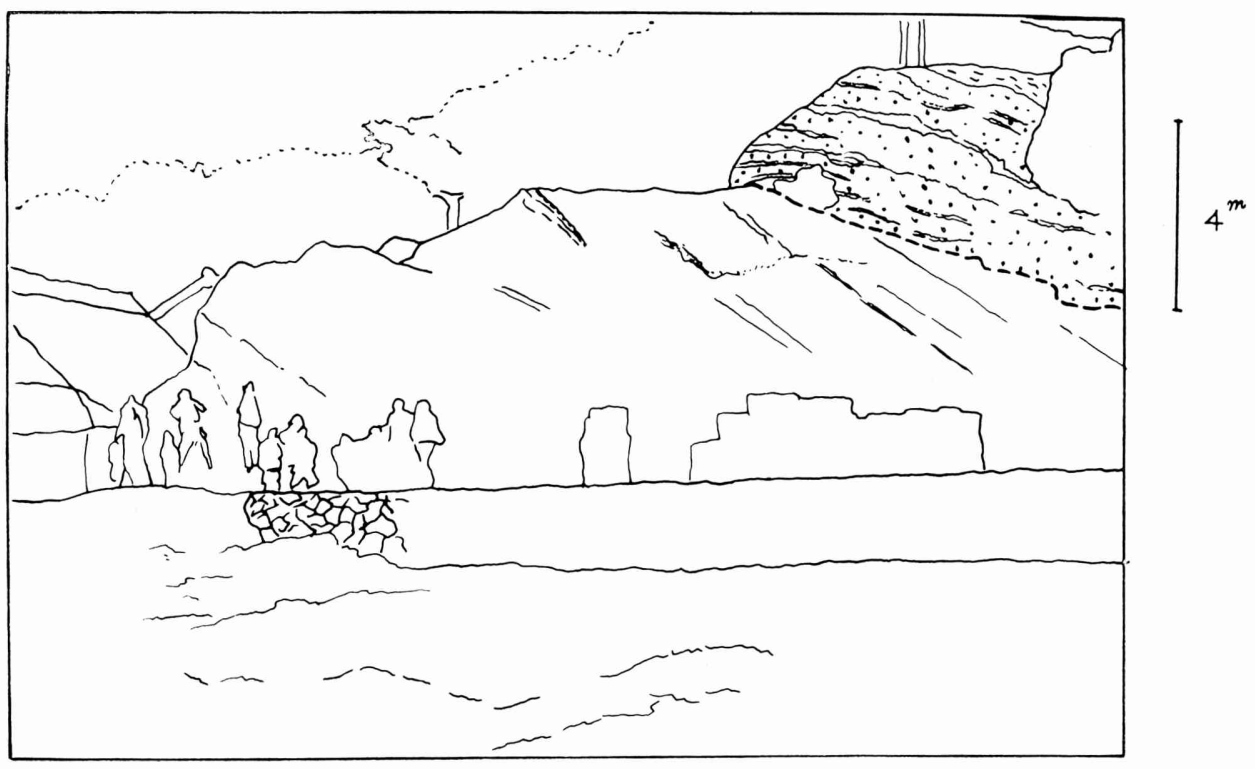

Fig. 3. Exposure of the unconformity at Usui, Nagashima. a: photograph; b: sketch.

consisting of poorly sorted, smaller (1-5 mm.) rock fragments of black siltstone (about $50 \%$ ), subangular granules of chert (next in abundance) and rhyolite and also angular fragments of granite (very rare). The basal part, about $4 \mathrm{~m}$. thick in this exposure, intercalates irregular, thin layers $(10-40 \mathrm{~cm}$.) of yellowish green shale. Its general attitude is $\mathrm{N} 60^{\circ} \mathrm{E}$ strike, $\mathrm{NW} 32^{\circ} \pm$ dip. Above this black conglomerate comes a $10 \mathrm{~m}$. sequence of more or less greenish, light grey, massive mudstone, followed by dark 
grey shale, $5 \mathrm{~m}$., with seams of poor coal and coaly shale, and then by a $30 \mathrm{~m}$. sequence of dark grey shale with occasional intercalates of arkosic coarse-grained sandstone. The above described basal member is about $50 \mathrm{~m}$. thick altogether. This is overlain by the conglomerate with interbeds of red and green shale - the main part (160 m.) of unit IV.

(2) Exposure at the northorn extremity of Ihara-jima (Fig. 4).-The plane of un-

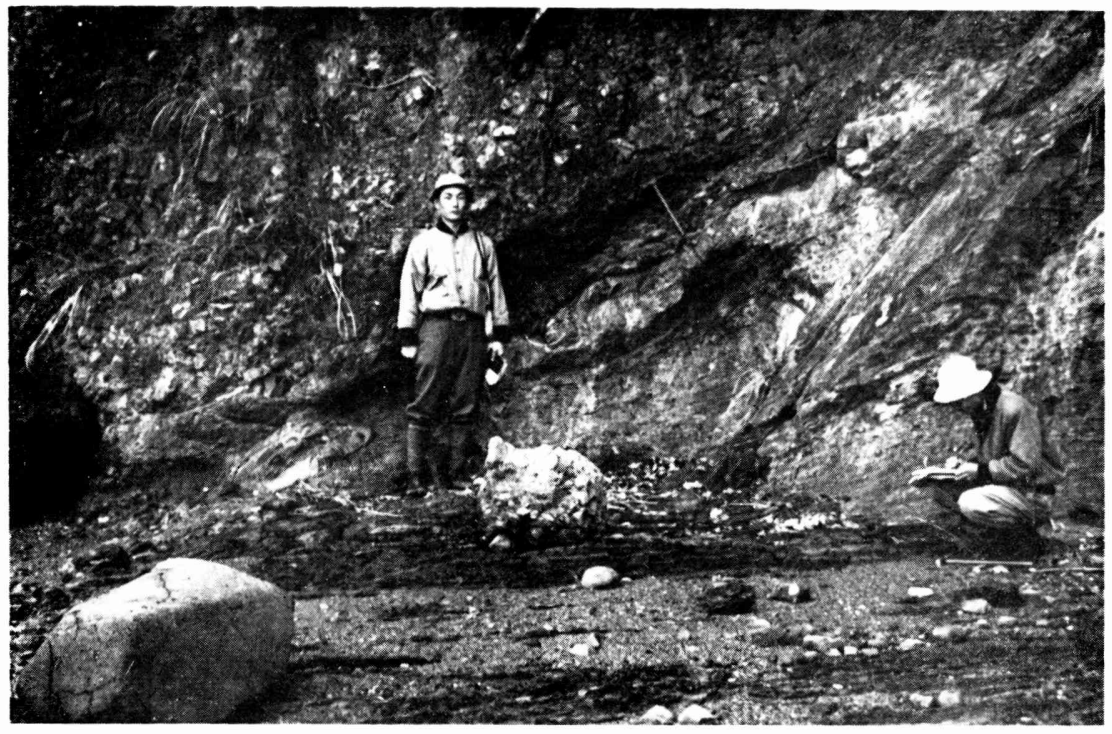

a

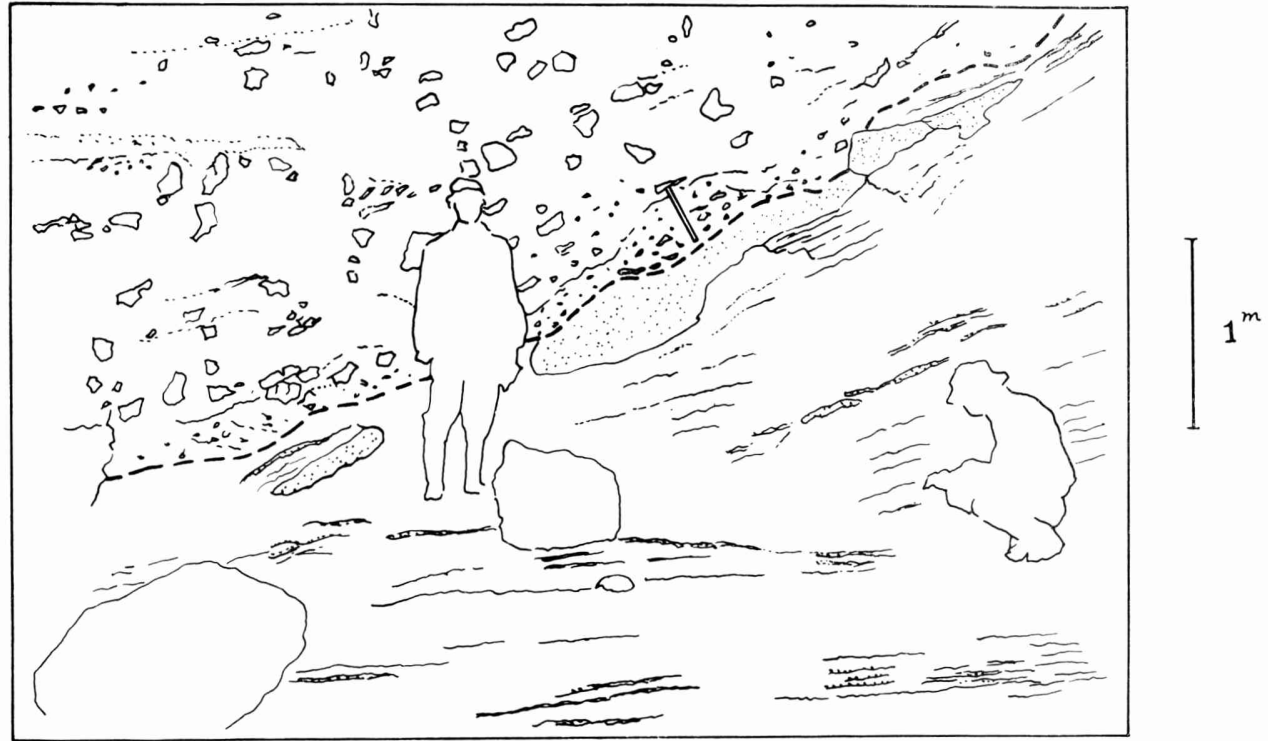

$\mathrm{b}$

Fig. 4. Exposure of the unconformity at the northern extre nity of Ikara-jima. a: photograph; b: sketch. 
conformity in this place shows a wavy undulation. The underlying Cretaceous part consists of alternating thin beds of dark grey shale $(5-10 \mathrm{~cm}$.) with fine sandy laminae and light grey fine-grained sandstone $(1-3 \mathrm{~cm}$.). Although the shale is predominant in this part, a lenticular irregular body $(40 \mathrm{~cm}$. in maximum thickness) of sandstone is intercalated in the uppermost portion. The Cretaceous strata take the general attitude of $\mathrm{N} 60^{\circ} \mathrm{W}$ strike, $\mathrm{NNE} 30^{\circ}$ dip, and are probably referable to unit III of the above description. The very base, about $40 \mathrm{~cm}$., of the Lower Tertiary part have subrounded pebbles $(2-3 \mathrm{~cm}$. in diameter) of medium-grained sandstone and angular smaller pebbles $(1 \mathrm{~cm} . \pm)$ of dark grey or greenish grey shale, with matrix of coarsegrained sandstone. This does not seem to form a definite, continuous bed but passes gradationally to the poorly sorted conglomerate, $3 \mathrm{~m}$. thick. The latter contains abundantly angular to subangular blocks $(20-5 \mathrm{~cm}$.) of medium-grained sandstone and subordinately subangular pebbles $(5 \mathrm{~cm}$. \pm ) of white siliceous rock. Irregular patches of very coarse-grained sandstone may occur as cross-beds in the conglomerate. The conglomerate is overlain by a bed $(1 \mathrm{~m}$.) of purplish brown shale and then by a $20 \mathrm{~m}$. sequence of massive, greenish grey mudstone. The succeeding $30 \mathrm{~m}$. is occupied by alternating beds of greenish grey to dark grey shale and greyish white, arkosic, medium-grained, sometimes cross-laminated, sandstone and then followed by $20 \mathrm{~m}$. dark grey shale with a number of thin intercalates of coaly seam or coaly shale. The attitude of the Lower Tertiary beds in this place is $\mathrm{N} 55^{\circ} \mathrm{E}$ strike, NNW26 \pm dip. This is certainly an extension of the basal part near Usui, but there is a considerable difference in the details of the lithofacies.

\section{General Remarks}

Although the area of exposure is narrow, the facts observed in Nagashima and vicinities are interesting for some geological problems. The available evidence from the related areas is to be brought into consideration, too. The remarks may be given in the following way.

(1) Zonation in the Upper Cretaceous Himenoura group.-The Himenoura group, which stretches from the type area in Amakusa-Kamishima northeasterly to Uto peninsula, Kumamoto Prefecture and southwesterly to Koshiki-jima, Kagoshima Prefecture in western Kyushu, is famous for its fossil contents, as has been palaeontologically worked out by YABE (1902), Yehara (1923), YABE and SHimizu (1924b, 1925), NAGaO (1930), Nagao and Matsumoto (1939-40), Kobayashi and Amano (1955), NAKANO (1957) and AMANO (1957, 1960a), etc.

From the fossil evidence the Himenoura group has been generally regarded as Senonian in age. More precise biostratigraphic subdivision is, howevr, necessary for further studies of geological problems. At the suggestion of MATsumoto the zonation of the Himenoura group has recently been attempted by UEDA and FURUKAWA (1960), with fine results. The zones established by them in the type area of the Himenoura group are in ascending order: 
(1) a part without zonal indices ...........K5 $\alpha(?)^{*}$

(2) zone of Inoceramus amakusensis .........K5 5 (lower)

(3) zone of Inoceramus japonicus.............K5 $\beta$ (upper) Santonian

(4) zone of Inoceramus orientalis ambiguus $\ldots\left\{\begin{array}{l}\mathrm{K} 5 \beta \text { (upper) } \\ \mathrm{K} 5 r\end{array}\right.$

(5) zone of Inoceramus balticus ............K6 $\alpha$

\} Campanian

Protexanites fukazawai (YABE and SHImIZU), among other ammonites, ranges from the upper part of the amakusensis zone to the lower part of the japonicus zone. Texanites cf. oliveti (BLANCKENHORN) which was discovered by MATSUMOTO (1955) is now confirmed to have come from the sility sandstone belonging to the lower part of the amakusensis zone. Probably because of the unfavorable environment, the coarse-grained beds below the amakusensis zone have no good zonal indices in the type area. In the Nagashima area, however, unit Ila in the lower part of the Himenoura group consists of the silty rock and contains Inoceramus cf. uwajimensis. It is a representation of the zone of $I$. uwajimensis in the Himenoura group and indicates $\mathrm{K} 5 \alpha$ (Lower Urakawan), i.e. Coniacian in terms of the international scale. Hitherto the uwajimensis zone has been traced to beds $\mathrm{O}_{5}$ in the Onogawa group near Oita, east Kyushu.

In the Nagashima area the zones of I. amakusensis and I. japonicus are not well recognized, but they should be in unit IIb which is now under the sea water. From the assemblage of the species Inoceramus elegans pseudosulcatus, I. cf. orientalis and I. balticus toyajoanus, unit IIIc in the present area most probably corresponds to the upper part of the ambiguus zone plus the lower part of the balticus zone in the type Amakusa area. This marks the first discovery of Inoceramus elegans pseudosulcatus in Southwest Japan. The type locality of the subspecies is in the basal part of the Hakobuchi group, slightly below the bed with abundant Inoceramus schmidti (K6 $\alpha$ ) and just above the bed with abundant Inoceramus orientalis (including $I$. orientalis ambiguus) (K5r) in Hokkaido.

(2) Base of the Lower Tertiary group of beds.-The Akasaki formation** was proposed by NAGAO (1922) for the basal unit of the Lower Tertiary group of strata in Amakusa-Kamishima, the eastern member of the twin islands of Amakusa. It is extended northeastward to Uto peninsula, Kumamoto Prefecture, and southwestward to Shishi-jima, Kagoshima Prefecture. It consists of red, purple, or variegated shale and sandstone with conglomerates in places and is generally regarded as continental deposits. Its thickness is 30 to $100 \mathrm{~m}$. in Amakusa and varies from place to place.

NAGAO $(1925,1928)$ subsequently used the name of the Akasaki formation not only for the one in the type area but also for the basal red-beds in various other part in northwestern Kyushu, such as those in Miike and Asakura coal fields in Fukuoka Prefecture, and Takashima and Sakito-Matsushima coal fields in Nagasaki Prefecture. In such a comprehensive case Matsushita (1949) prefers the term Aka-

* For the definition of $\mathrm{K} 5 \alpha, \mathrm{K} 5 \beta, \mathrm{K} 5 \gamma, \mathrm{K} 6 \alpha$ the reference is to be made to Matsumoto [Editor], 1954 and Matsumoto, 1959.

**赤崎層 
saki group. The representative of the group in Takashima, for example, exceeds $1200 \mathrm{~m}$., as estimated by SAKAKURA (1953), and the non-red coarse-grained sandstone predominates in the lower part in which only few red beds are intercalated. Anyhow, the thickness and detailed lithology vary from place to place. Either the underlying rock below the basal unconformity of the group is not the same-Upper Cretaceous in the Amakusa-Uto area, granite and schists in the Miike and Asakura areas, another granite in the Sakito-Matsushima area and schists with amphibolite in the Takashima area.

The basal unit (IV) of the Lower Tertiary strata in the Nagashima area is to be referred to the Akasaki formation. It has red-beds and conglomerate of the facies of the type Akasaki formation, although it is somewhat thicker. Whether the succeeding unit (V) of granule-conglomerate is upper Akasaki or lower Shirataki or otherwise (see HATAE, 1960a) may be debatable, but it has intercalates of grey shale and no red-beds and seems to be intimately related to the succeeding, fossiliferous, black siltstone unit (the so-called Nummulites beds). Anyhow the coarse-grained sediments and red-beds, altogether, below the beds with Nummulites, Colpospira (Acutospira), and/or Orthaulax are much thicker $(360 \mathrm{~m}$. $)$ in the Nagashima area than those in the area of Amakusa-Kamishima and Uto peninsula.*

On the other hand in Amakusa-Shimojima, the western member of the twin islands of Amakusa, the Fukami sandstone ${ }^{2 *}$ (NAGAO, 1922) was once regarded as an equivalent of the Akasaki formation in different facies. Recently MATSUSHITA et al. (1959) redefined the Fukami formation as a unit of bluish, greenish grey sandstone with subordinate conglomerate and shale $(180 \mathrm{~m}$. thick in the type section) which rests on the unmistakable Cretaceous (probably Campanian) beds and is overlain with a significant unconformity by the Eocene, fossiliferous Fukuregi ${ }^{3 *}$ beds. As is described in detailed in another paper (TAKAI, 1961), it is almost certain that the so-called Fukami formation is mostly to be referred to the uppermost unit of the Himenoura group in this area and that the base of the Lower Tertiary group of beds is at the base of the Fukuregi formation ${ }^{4 *}$. This is correlated to the Shiratake formation (including Nummulites beds), because it contains Nummulites amakusensis, Discocyclina sp., Colpospira (Acutospira) tashiroi, C. (A.) okadai and other fossils. The Nummulites beds in west Kyushu is regarded by YABE and HANZAwA (1925) as representing Ypresian or Lower Lutetian.

All these and other facts strongly suggest that the base of the Lower Tertiary group of beds may not be everywhere of the same age but shifts in age from place to place. In other words the basal formation may represent Middle to Lower Eocene in some places but could also include a part of Paleocene in other places as in the

* In Uto peninsula the basal unit referable to the Akasaki formation is $200 \mathrm{~m}$. thick below the fossiliferous Shiratake sandstone. Its lower part $(100 \mathrm{~m}$.) has predominant red-beds, but its upper part $(100 \mathrm{~m}$.) has arkosic sandstone similar to the unmistakable Shiratake and only a few, thin red-beds at its top.

2* 深海砂岩, *3 福連木層

4* The Akashimisaki formation of HATAE (1960) at its type lccolity is regarded as an extension of the Fukuregi formation (MATSUshita, 1949). 
case of Nagashima and Takashima where the base is far apart downward from the Nummulites beds. Fossil evidence, if any at all, from the Akasaki group itself would be a key to answer this question.

(3) Structural relationship between the Cretaceous and Tertiary rocks.-There was once a current view that the relation between the Upper Cretaceous and Lower Tertiary rocks in Southwest Japan is a paraunconformity which represents gentle warping, without folding or thrusting (e.g. OTUKA, 1935; KoBAYASHI and OTUKA, 1937 ; KobAyASHI, 1941). Recent field evidence, however, is not congruent with this opinion. UEDA and Furukawa (1960) demonstrate the structural discordance between the Himenoura and Lower Tertiary groups of strata in Amakusa-Kamishima and call the folding at the end of the Cretaceous the Himenoura folding. They hold that this is more intense than the post-Eocene Amakusa folding and that even the trends of the fold axes somewhat deviate (from NE to NNE) between the two. AmAno (1960b) likewise reported the Cretaceous-Tertiary structural discordance in Maki-shima,* one of the satellite islets in Amakusa.

In the Nagashima area the unconformity marks a very distinct structural angularity; the base of the Akasaki formation cuts quite obliquely the beds of the Cretaceous at varicus horizons from the upper Goshonoura (Turonian ?), through the uwajimensis zone (Coniacian), to the balticus zone (Campanian). The structural discordance between the Cretaceous and Lower Tertiary beds in this area is probably greater than in Amakusa, although the structural pattern manifested by the Cretaceous beds are only narrowly exposed.

The Median Dislocation Line, which longitudinally runs in Southwest Japan, probably has a long history of development. Prior to the displacement in a certain epoch of Tertiary period, its important activity took place at about the end of Cretaceous or the beginning of Tertiary period, as has been already pointed out by YABE (1925). His eminent view was once unfortunately denied, but the post-Izumi group (Campanian and Maestrichtian) and pre-Eofabiania bearing Kuma formation (Middle Eocene) activity in Shikoku is evident (NAGAI, 1958). In Kyushu there is a debate about the position of the extension of the Median Line. Its divergence into at least three lines, Matsuyama-Imari, Oita-Kumamoto and Usuki-Yatsushiro Lines, may be the true state. Their ages of activity have not been precisely analysed, but the activity of at least the southern two of them must be intimately related to the deformation of the Upper Cretaceous beds such as the Tano and Tomochi formations and also the Onogawa and Mifuné groups (see Matsumoto [Editor], 1954). Although Lower Tertiary fossiliferous beds are nowhere found in contact with the two lines, a phase of the deformation and displacement is probably contemporaneous with that in Shikoku and also with that represented by the structural unconformity between the Upper Cretaceous and Lower Tertiary groups of beds in the region of Amakusa and Nagashima.

The enormously thick accumulation of the Izumi sandstone group, which extends

\footnotetext{
* 牧島
} 
in the present day geological map along the north side of the Median Dislocation Line in Shikoku and Kinki, is intimately related with the upheaval and erosion of the area of predominant acid igneous (volcanic, hypabyssal and plutonic) rocks which were probably the main constituents of the Chugoku Mountains in late Late Cretaceous (see Matsumoto [Editor], 1954, p. 137). The granitic batholith in the Chugoku Mountains certainly extends to northern Kyushu, where successive emplacement of the granitic rocks took place in the Late Cretaceous. These granitic bodies of northern Kyushu are overlain in many places by the Lower Tertiary (mainly Eocene) coal measures with a distinct unconformity. The Akasaki formation rests on one of them in the Miike coal field. Poorly sorted conglomerate, coarse-grained sandstone and red beds of the Akasaki formation in various places indicate the high topographic relief and the rejuvenation of erosion which were resulted from the latest Cretaceous-earliest Tertiary disturbance. In other words the Akasaki formation is a kind of post-orogenic sediments.

Summarizing all the above remarks, it can be concluded that the unconformity at the base of the Lower Tertiary group of beds marks an important phase of the tectonic movements.

\section{Acknowledgements}

We wish to thank Professor Hisamichi Matsushita for advice and discussion freely given during the course of this study. We are indebted to Dr. Masaru KanEkO, Director of the Geological Survey of Japan, for the support to the field and laboratory works and for kind permission to publish the results in this Memoir, to Drs. Atsuyuki Mizuno, Katsuro Oyama and Osamu Fukuda for help in the identification of the Tertiary fossils and to Messrs. Tomosuke Sujaku and Kazuwo MoRI of the Mitsubishi Mining Company for kind information about fossil localities and field geology of the northern Nagashima area.

\section{References Cited}

Amano, Masahisa (1957): Upper Cretaceous molluscan fossils from Shimo-Koshiki-jima, Kyushu. Kumamoto Jour. Sci., [B], sec. 1, Geol., 2, (2), 51-75, incl. pls. 1-2.

- (1960a): Geology of Tobase-jima and Senzokuzōzō-jima, Amakusa, Kumamoto Prefecture. Ibid., 4, (1), 1-12, 1 p1., 1 map.

- (1960b): Geology of Maki-shima and its neighboring islands, Amakusa, Kumamoto Prefecture. Jour. Geol. Soc. Japan, 66, (783), 767-779.*

Hatae, Nobuhiro (1960a): The geology and the geologic structure of Amakusa-Shimo-jima, Kumamoto Prefecture. Sci. Rep. Kagoshima Univ., 9, 61-107, 1 map.*

(1960b): On the Nummulites zone of the islands of Amakusa, Kyushu, Japan. Sci. Rep. Tohoku Univ., [2], Special Vol. (4), [Prof. Shoshiro Hanzawa Memorial Volume], 411-423.*

IMAI, Hanjiro (1924): The stratigraphical relation between the coal-bearing Tertiary (the Ishikari series) and the Cretaceous deposits in the Ishikari coal-field. Jour. Geol. Soc. Tokyo $[$ Japan $], 31,(364,5,6,7,8,9), 18-39,60-81,95-109,131-154,187-210 . * *$

* in Japanese with English abstract.

** in Japanese without abstract of European language. 
Kobayashi, Teiichi (1941): The Sakawa orogenic cycle and its bearing on the origin of the Japanese Islands. Jour. Fac. Sci., Imp. Univ. Tokyo, sect. 2, 5, (7), 219-578, pls. 1-4, maps $1-10$.

- and Amano, Masahisa (1955): On the pseudoquadratae Trigonians, Steinmannella, in the Indo-Pacific province. Japan. Jour. Geol. Geogr., 27, (3-4), 193-208, pls. 13-15.

- and OtukA, Yanosuke (1937): Geotectonics of Southwest Japan and the Mesozoic palaeogeography, Pt. 6. Jour. Geol. Soc. Japan, 44, (528), 822-836.**

Matsumoto, Tatsuro (1938): Geology of Goshonoura Island, Amakusa-with special reference to the Cretaceous stratigraphy. Jour. Geol. Soc. Japan, 45, (532), 1-47, pls. 1-3.*

- (1959): Zonation of the Upper Cretaceous in Japan. Mem. Fac. Sci., Kyushu Univ., [D], Geol., 9, (2), 55-93, pls. 6-11.

(1960): Cretaceous-Tertiary boundary in the Japanese Islands. Rep. Intern. Geol. Congr., XXI Session, Norden, 1960, pt. 5, 50-56, Copenhagen.

Matsumoto [Editor] (1954): The Cretaceous System in the Japanese Islands. $14+324$ p., 36 pls., Tokyo (for 1953).

Matsushita, Hisamichi, (1949): The Palaeogene stratigraphy of northern Kyushu. Sci. Rep. Fac. Sci., Kyushu Univ., Geol., 3, (1), 1-57, 13 palaeogeogr. maps, 7 geol. maps, 1 table.**

-, R. Takahashi, J. Obara, T. Iwahashi and E. Inoue (1956): On the Older Tertiary geology of northern Kyushu. Yukochu [Foraminifera], 5, 13-22, 1 chart.**

$\longrightarrow$, Y. Takai, R. Takahashi, H. Urata, T. Iwahashi, J. Obara, S. Tomita and K. Ota (1959): Cretaceous-Tertiary boundary in Amakusa-Shimojima. Ibid., 10, 30-41, 2 charts.**

Nagal, Kozo (1958): The Median Dislocation Line in Western Shikoku. Jubilee Pub. Comm. Prof. H. Fujimoto's 60th Birthday, 282-288.*

NaGAO, Takumi (1922): Geology of the Islands of Amakusa. Jour. Geol. Soc. Tokyo [Japan], 29, (341, 342), 41-56, 90-100.**

(1924): On the boundary of the Cretaceous and Tertiary formations in Kyushu. Ibid., 31, (371-2), 277-283.**

(1925): Stratigraphical boundary between the Cretaceous and Tertiary strata of Kyushu. Japan. Jour. Geol. Geogr., 4, (1-2), 55-64, pl. 1.

(1928): A summary of the Palaeogen stratigraphy of Kyushu, Japan, with some accounts on the fossiliferous zones. Sci. Rept. Tohoku Imp. Univ., [2] Geol., 12, (1), 1-10, pl. A.

(1930): On some Cretaceous fossils from the Island of Amakusa, Kyushu, Japan. Jour. Fac. Sci., Hokkaido Imp. Univ., [4], 1, (1), 1-25, pls. 1-3.

- and Matsumoto, Tatsuro (1939-40): A monograph of the Cretaceous Inoceramus of Japan. Jour. Fac. Sci., Hokkaido Imp. Univ., [4], 4, (3-4), 241-299, pls. 23(1)-34(12) [1939]; Ibid., 6, (1), 1-64, pls. 1-22 [1940].

NaKano, Mitsuo (1957): On the Cretaceous pennatae Trigonians in Japan. Japan. Jour. Geol. Geogr., 28, (1-3), 107-120, pls. 8-9.

Otuka, Yanosuke (1935): Median Dislocation Line of Southwest Japan and the Nagasaki “Dreiecke". Bull. Earthq. Res. Inst., Tokyo Imp. Univ., 13, 457-468.*

(1939): Tertiary crustal deformations in Japan (with short remarks on Tertiary palaeogeography). Jubilee Pub. Comm. Prof. H. YABE's 60th Birthday, 481-519.

SaKakura, Katsuhiko (1953): Submarine electrical prospecting at the Takashima coal field. Min. Geol., 3, (8), 95-107.*

TAKAI, Yasuaki (1961, MS.) : Geology of Amakusa-Shimo-jima, Kyushu. Bull. Geol. Surv. Japan (in press).**

Tokunaga, Shigeyasu (1923): Mesozoic strata discovered in the Iwaki coal field. Jour. Geol. Soc. Tokyo, 30, (354), 101-114, pl. 2.**

Ueda, Yoshiro and Furukawa, Nobutsune (1960): On the Himenoura group of AmakusaKamishima and adjacent islets, Kumamoto Prefecture. Sci. Rep. Fac. Sci., Kyushu Univ., Geol., 5, (1) 14-35, 1 map.*

YABE, Hisakazu (1902): Notes on three Upper Cretaceous ammonites from Japan, outside of 
Hokkaido. Jour. Geol. Soc. Tokyo [Japan], 9, (English pages), 1-7, pl. 1.

- (1925): The Nagasaki Triangle of Ferdinand von Richthofen. Ibid., 32, (381), 201$209 . * *$

(1927) : Cretaceous stratigraphy of the Japanese Islands. Sci. Rep. Tohoku Imp. Univ., [2], Geol. 11, (1), 28-100, pls. 3-9.

and Hanzawa, Shoshiro (1925): Nummulitic rocks of the islands of Amakusa (Kyushu, Japan). Ibid., 7, (3), 73-82, pls. 18-22.

and Shimizu, Saburo (1924a): Stratigraphical sequence of the Lower Tertiary and Upper Cretaceous deposits of Russian Saghalin. Japan. Jour. Geol. Geogr., 3, (1), 1-12.

- (1924b): A new species of Nautilus, N. (Cymatoceras) pseudoatlas YABE and Shimizu, from the Upper Cretaceous of Amakusa. Ibid., 3, (1), 41-43, pl. 5.

(1925): Japanese Cretaceous ammonites belonging to Prionotropidae, I. Sci. Rep. Tohoku Imp. Univ., [2], Geol. 7, (4), 125-138, pls. 30-33.

YeHARA, Shingo (1923): Cretaceous Trigoniae from Amakusa Islands, Prov. Higo, Kyushu, Japan. Jour. Geol. Soc. Tokyo, 30, (356), 1-12, pls. 4-7. 


\title{
Appendix
}

\section{Palaeontological Notes}

\author{
By
}

\section{Tatsuro Matsumoto}

Brief notes are given below on some of the fossils from the Cretaceous of the Nagashima-Takenoshima area.

Inoceramus cf. uwajimensis YEHARA

P1. 11, figs. 2-4

1924. Inoceramus uwajimensis Yehara, Japan. Jour. Geol. Geogr., vol. 3, p. 36, p1. 3, fig. 2.

1939. Inoceramus uwajimensis, NAGAO and MAtsumoto, Jour. Fac. Sci., Hokkaidô Imp. Univ., ser. 4 , vol. 4 , nos. $3-4$, p. 286 , pl. 34 (11), figs. $1,3,4,6$; pl. 35 (12), figs. 1-3.

Lectotype of Inoceramus uwajimensis.-The specimen figured by YEHARA (1924) on pl. 3, fig. 2, from Furushiroyama near Uwajima, Ehime Prefecture (=Prov. Iyo) southwestern Shikoku, is designated as the lectotype. As NAGAO and MATsumoto (1939, p. 288) remarked, other specimens figured by YEHARA (1924) under the same specific name are not typical. Those on pl. 3, fig. 1 and pl. 4, fig. 2 are Inoceramus uwajimensis var. yeharai NAGAO and MATSUmoto, 1939 and those on pl. 4, figs. 1 and 2 are probably to be referred to Inoceramus hobetsensis NAGAO and MATSUMoto, 1939.

Description.-The specimens, from loc. 7 near Usui in the northern part of Nagashima, are represented by casts. The figured ones are KG. 0701, KG. 0702, and KG. 0703, all collected by Y. TAKAI. Other specimens are much more deformed.

The characteristic features of the shell represented by these specimens are (1) a high and roughly oval outline, with a triangular dorsal and a semicircular ventral margin, (2) a moderate to low convexity of the valve, being more convex near the umbo, and (3) low but sharp headed concentric ridges without notable concentric rings.

All these features at once remind us of Inoceramus uwajimensis YeHARA, to which the present specimens are most probably identified.

Remarks.-Inoceramus uwajimensis YEHARA is closely allied to Inoceramus stantoni Sokolow (1914, p. 52) [=Inoceramus acuteplicatus STANTon, 1899]. The examples from North Saghalien were indeed regarded by Sokolow (1914, p. 52, p. 88, pl. 5, figs. 7,8 ) as identical to STANTON's species from the Colorado group of North America, but I hesitate to conclude the specific identity between Inoceramus uwajimensis YEHARA and Inoceramus stantoni SOKOLOW from the following reason.

The right valve of Inoceramus stantoni SoKolow, as represented by STANTON's 
original specimens (Inoceramus acuteplicatus STANTon, 1899, p. 75, fig. 10, pl. 76, fig. 1), is very closely similar to, and accordingly almost indistinguishable from, that of Inoceramus uwajimensis YEHARA. As far as the described specimens are concerned, the left valve of the former has the umbo which is more strongly curved inward and forward than that of the latter. I have recognized this distinction by comparing one of STANTON's specimens (pl.75, fig. 9), USNM. 28951, with typical examples from Hokkaido (e.g. Sd. 22773, NAgAo and Matsumoto, 1939, pl. 33 [11], fig. 1a-c). In other words Inoceramus stantoni Sokolow from the Western Interior of North America seems to be more inequivalve than Inoceramus uwajimensis YEHARA from the Northern Pacific region.

There might be a variation in this respect and this separation could be justified as subspecific. Until sufficient evidence is obtained for admitting this possibility, the specific name Inoceramus uwajimensis is to be used. Sokolow's examples from Saghalien may be better called Inoceramus uwajimensis. A point which would give difficulty in clear solution of the nomenclature is that STANTON (1899) originally designated a large right valve (pl. 76, fig. 1), USNM. 28950 A, as "a principal type specimen", which should mean the holotype, of his Inoceramus acuteplicatus. Some of the Japanese examples of $I$. uwajimensis reach this large size, too. Therefore, when the right valves only are treated, the distinction is very difficult.

Occurrence.-Loc. KG 07, near Usui, Nagashima, from the lower part of the Himenoura group. The specimens are contained abundantly in a particular part of the black siltstone. In other places of the Japanese Islands, Inoceramus uwajimensis occurs in abundance, sometimes in muddy rock, sometimes in sandstone, and even in conglomerate. It characterizes the zone of Inoceramus uwajimensis in the Lower Urakawan [ $\fallingdotseq$ Coniacian] of Japan. Inoceramus cf. uwajimensis is furthermore found. in Alaska and California (MATsumoto, 1959, 1960).

\section{Inoceramus cf. balticus toyajoanus NAGAO and MATSUMOTO}

$$
\text { P1. 11, fig. 1; P1. 12, fig. } 3
$$

1915. Inoceramus cf. regularis, YABE, Sci. Rep. Tohoku Imp. Univ., 2nd ser., Geol., p. 22, pl. 3, fig. 3.

1940. Inoceramus balticus Boenm var. toyajoanus NAGAo and MAtsumoto, Jour. Fac. Sci., Hokkaido Imp. Univ., ser. 4, vol. 6, no. 1, p. 20,

Lectotype of Inoceramus balticus toyajoanus.-NAGAO and MATSUMoto (1940, p. 20) described two specimens as typical examples of variety toyajoanus, of which the one figured by $\mathrm{YABE}_{\mathrm{ABE}}(1915$, pl. 3, fig. 3) is here designated as the lectotype of Inoceramus balticus toyajoanus. It came from the Toyajo formation (K6 $\alpha$, Campanian), Wakayama. Prefecture (Province Kii).

Subspecific diagnosis.-Inoceramus balticus toyajoanus is characterized by a uniform, low to moderate inflation of the valves, with a flattened posterodorsal area, a very inequilateral outline extending obliquely towards the posteroventral margin, a very long hinge-line, regular and rather low concentric ribs separated by slightly broader concave interspaces and fine concentric rings covering both the ridges and 
interspaces. It is distinguished from Inoceramus balticus balticus BоEнM (1907, p. 113, holotype of which by original designation is the specimen of Inoceramus cripsii, GolDFUSS, 1836 [non I. crippsi MANTELl, 1822], Petref. Germ., vol. 2, p. 116, pl. 112, fig. 4b only, from the "Lower Quadratus beds" of Dülmen) by the less inflation of the valve and the lower concentric ridges.

The two subspecies are intimately related to but are not always associated with each other, having presumably some ecological difference, although they may be nearly contemporary.

Whether or not Inoceramus balticus BоEнM is identical to Inoceramus subundatus MEEK (1876a, p. 358, pl. 3, figs. 1, 1a, 3, 3a) [=Inoceramus cripsii var. subundatus MEEK, 1862, p. 315] or to Inoceramus barabini MoRTON (1834, p. 62, pl. 17, fig. 3) [=Inoceramus cripsii ? var. barabini, MEEK, 1876 b, p. 49 , pl. 13 , fig. 1a-c; pl. 12, fig. 3] may be a question to be settled. This is not the place to discuss it further, but I have recognized that the concentric rings are much weakened or obsolete in the American examples (MEEK's types). For the time being I admit the specific distinction.

Description of the Takeno-shima examples.-An external mould, KG. 0301, and an internal mould, KG. 0302, from loc. KG 03, Kita Takeno-shima, collected by Y. TAKAI, are incompletely preserved but probably to be referred to Inoceramus balticus toyajoanus. The concentric rings are better impressed on the former (Pl. 11, fig. 1) and can also be discernible on a part of the latter (Pl. 12, fig. 3). The posteroventrally extended outline, long hinge line, relatively regular concentric ribs and other diagnostic features of Inoceramus balticus are well shown in the latter. Although the shells are secondarily compressed, they can be interpretted as originally less inflated and their concentric ridges are relatively low. Some of the concentric ridges are intercalatory as in many other examples of $I$. balticus (s. 1.). Minor radial riblets or grooves can be seen on the internal mould. They probably reflect the internal structure of the shell and cannot be considered as a specific character.

Occurrence.-The described specimens came from loc. KG 03 in Kita Takeno-shima which is in black shale with sandy laminae of the visible highest unit (IIIc) of the Himenoura group in this area. Inoceramus balticus toyajoanus NAGAO and MATSUMOTO originally came from the upper (not uppermost) part of the Toyajo group in Wakayama Prefecture which is most probably assigned to the Lower Hetonaian (K6 $\alpha)$ in the Japanese scale, Middle to Upper Campanian. The examples of the same subspecies and the comparable specimens occur fairly commonly in the relatively upper part of the Himenoura group in the type area, forming a zone evidently higher than the zone of Inoceramus japonicus and usually above that of Inoceramus orientalis ambiguus, although some specimens begin to appear already in the ambiguus zone (see UEDA and Furukawa, 1960).

Inoceramus elegans pseudosulcatus NAGAO and MATSUMOTO

P1. 12, figs. 1,2

1940. Inoceramus pseudosulcatus $\mathrm{NAGAO}$ and MAtsumoto, Jour. Fac. Sci., Hokkaido Imp. Univ., ser. 4 , vol. 6 , no. 1 , p. 48 , pl. 21 , fig. 3 ; pl. 22, fig. 2a-c. 
Lectotype.-NAGAO and Matsumoto (1940, p. 48) established I. pseudosulcatus on four syntypes, of which the one figured on pl. 22, fig. 2a-c, No. 5988a, Hokkaido University, is designated herein as the lectotype of I. elegans pseudosulcatus.

Description.-Two internal moulds, KG. 0101 and KG. 0102, from loc. KG 01, KitaTakeno-shima, collected by Y. TAKAI, are before me. They are small, slightly less than $25 \mathrm{~mm}$ in height.

The observable characteristic features are (1) the small size of the shell, (2) a high and narrow outline of the shell, with an incurved umbo, a considerably inflated umbonal region and a posterior wing distinctly separated from the main part of the valve, (3) three, strong, radial ribs, appearing near the umbo and running almost straight towards the ventral margin, and a few, shorter, radial ribs on the anterior part independently or as intercalatories and (4) the concentric ribs which give rise to an nodulous appearance to the radial ribs on crossing.

All the above features fall in the specific diagnosis of Inoceramus pseudosulcatus NAGAO and MatSUMOTO (1940) in their original description.

Remarks.-NAGAO and MATSumoto (1940, p. 49) described Inoceramus elegans Sokolow, 1914 as a variety of their $I$. pseudosulcatus. As the specific name elegans obviously has priority over pseudosulcatus and their pseudosulcatus should have been called Inoceramus elegans var. pseudosulcatus. Now this "variety" is to be regarded as more than a mere variety of I. elegans. The subspecific separation can be justified as follows :

Inoceramus elegans elegans, with the measured and figured specimen of SoKOLOW (1914, p. 37, pl. 1, figs. 3, 4) as the lectotype, in which the radial ribs appear in the late growth stage and the earlier part has only concentric ribs of $I$. naumanni type (see NAGAO and Matsumoto, 1940, p. 33-35, text-fig. 4).

Inoceramus elegans pseudosulcatus, in which strong radial ribs appear very early in the growth stage and are persistent throughout life.

Stratigraphically the former begins to appear somewhat earlier than the latter and, accordingly, represents the earlier stage in the evolution. I have examined the examples from more than fifteen localities but I do not know any case in which the two subspecies coexist, although they may be partly overlapping in geological age.

The similarity between Inoceramus sulcatus PARKINSON (see Woods, 1911, p. 269, pl. 47, figs. 15-20) and I. elegans pseudosulcatus or between Inoceramus concentricus subsulcatus WiltshiRe (see Woods, 1911, p. 268, pl. 47, figs. 3-14) and I. elegans elegans is an interesting example of the heterochronous homeomorphy. Inoceramus elegans is equivalve as in other species of Inoceramus naumanni, while Inoceramus concentricus and $I$. sulcatus are distinctly inequivalve.

Occurrence.-The described specimens were found in a black shale of northern islet of Takeno-shima, Higashi-machi, Izumi-gun, Kagoshima Prefecture. The shale belongs to the highest unit of the Himenoura group in this area. Among the associated species there is Inoceramus sp. cf. I. orientalis Sokolow.

Inoceramus elegans elegans and Inoceramus elegans pseudosulcatus have been known only in Hokkaido and Saghalien [Sakhalin]. They are from the uppermost Urakawan $[\mathrm{K} 5 \gamma]$ and the Lower Hetonaian $[\mathrm{K} 6 \alpha]$, Campanian in terms of the inter- 
national scale. (I. elegans elegans appears already in the upper $\mathrm{K} 5 \beta$, upper Santonian.) This is in harmony with the stratigraphic position in the present area. The geographical distribution of the species has now proved to be extended to southwest Kyushu. The known examples mostly came from the sandstone or sandy siltstone. Although the present specimens were in a black shale, the unit itself has some sandy intercalates (see description in p. 261), representing an extension of the upper sandstone and shale formation of the Himenoura group-a regressive phase in a marine cycle of sedimentation.

Acknowledgements.-I very much appreciate the collection of Mr. Yasuaki TAKAI of the Geological Survey of Japan who has provided me the better preserved specimens for study. I have examined for comparison the undescribed specimens from the type Himenoura group which were obtained by Messrs. Yoshiro UEDA and FURUKAWA and also some type specimens preserved at the British Museum (Natural History), Geological Survey and Museum, London and United States National Museum, Washington, D.C. by courtesy of the curators.

\section{References Cited}

Boehm, Johanes (1907): Über Inoceramus cripsii Mantell. Zeitschr. deutsch. geol. Gess., 59, Monatsber. (4), 113-114.

Goldfuss, A. (1836): Petrefacta Germaniae, 2.

Mantell, G. A. (1822): The fossils of the South Downs, or illustration of the geology of Sussex. London.

Matsumoto, Tatsuro (1959): Cretaceous ammonites from the Upper Chitina Valley, Alaska. Mem. Fac. Sci., Kyushu Univ., [D], Geol., 8, (3), 49-90, pls. 12-29.

- (1960): Upper Cretaceous ammonites of California, Part III. Mem. Fac. Sci., Kyushu Univ., [D], Geol., Special vol. 2, 1-204, pls. 1-2.

Meek, F. B. (1862): Descriptions of new Cretaceous fossils collected by the Northwestern Boundary Commission on Vancouver and Sucia Islands. Acad. Nat. Sci., Philadelphia, Proc., 13, (1861), 316.

(1876a): Descriptions and illustrations of fossils from Vancouver and Sucia Islands and other northwestern localities. Bull. U. S. Geol. Geogr. Surv., Terr., 2, (4), 351-374.

(1876b) in MeEK, F. B. and HAYden, F. V. (1876): A report on the invertebrate Cretaceous and Tertiary fossils of the Upper Missouri Country. Rep. U.S. Geol. Geogr. Surv. Terr., 9, 629 p., 45 pls.

Morton, S. G. (1834): Synopsis of the organic remains of the Cretaceous group of the United States, 88 p., 19 pls., Philadelphia.

Nagao, Takumi and Matsumoto, Tatsuro (1939-1940): A monograph of the Cretaceous Inoceramus of Japan, Parts 1, 2. Jour. Fac. Sci., Hokkaidô Imp. Univ., [4], 4, (3-4), 241-299, pls. 23 (1)-34 (12) (1939); Ibid., 6, (1), 1-64, pls. 1-22 (1940).

Sokolow, D. W. (1914): Kreideinoceramen des russischen Sachalin. Mém. Comité géol., [N.S.], 83, 95 p., 6 pls.

Stanton, T. W. (1899) in Hague, Arnold et al. (1899): Geology of the Yellowstone National Park, Pt. 2, Chap. 13, Mesozoic fossils. Mon. U.S. Geol.Surv., 32, (2), 600-650, pls. 72-76.

Ueda Yoshiro and Furukawa, Nobutsune (1960): On the Himenoura group of AmakusaKamishima and adjacent islets, Kumamoto Prefecture (in Japanese with English abstract). Sci. Rep. Fac. Sci., Kyushu Univ., Geol.,, 5, (1), 14-35.

Woods, Henry (1911-1912): A monograph of the Cretaceous Lamellibranchia of England, 2, Pts. 7, 8 (Inoceramus). Palaeontogr. Soc., 1910, 262-284, pls. 45-50 (1912) ; Ibid., 1911, 285- 
340, pls. 51-54 (1912).

YABE, Hisakatsu (1915): Notes on some Cretaceous fossils from Anaga on the island of Awaji and Toyajo in the province of Kii. Sci. Rep. Tôhoku Imp. Univ. [2] Geol. 4, (1), 13-24, pls. 1-4.

YeHARA, Shingo (1924): On the Izumi-sandstone group in the Onogawa basin, Prov. Bungo, and the same group in Uwajima, Prov. Iyo. Japan. Jour. Geol. Geogr., 3, 27-40, pls. 2-4.

Postscript. Regarding the type-locality of Inoceramus elegans pseudosulcatus, there is an inconsistency in the text and the explanation of plate in NAGAO and MATSUмото, 1940 (cf. p. 49 and p. 63). Thanks to the kind help of Professor SASA and Dr. Uwozumi, I have confirmed that the original locality of the lectotype, Hokkaido University No. 5988a, is in Shidanosawa, Horokakuriki, Yubari (Momijiyama quadrangle, $1: 50000$ ), Hokkaido. 


\section{Tatsuro MATsumoto}

Palaeontological Notes

in

Yasuaki TAKAI and Tatsuro MATsumoto

Cretaceous-Tertiary Unconformity in Nagashima, Southwest Kyushu

Plates 11-12 
Plate 11 


\section{Explanation of Plate 11}

Fig. 1. Inoceramus cf. balticus toyajoanus NAGAO and MAtsumoto ................ 274 KG 0301 from loc. KG 03, unit IIIc, Kita Takeno-shima, Izumi-gun, Kagoshima Prefecture (Y. TAKAI Coll.)

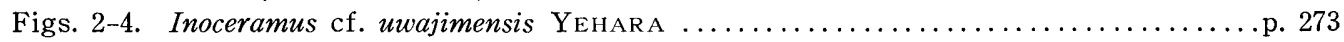
KG 0703 (Fig. 2), KG 0702 (Fig. 3) and KG 0701 (Fig. 4), all from loc. KG 07, near Usui, Nagashima, Izumi-gun, Kagoshima Prefecture (Y. TAKai Coll.)

(All figures of natural size, taken from the plaster-casts.)

Photos by Yasuaki TAKAI. 


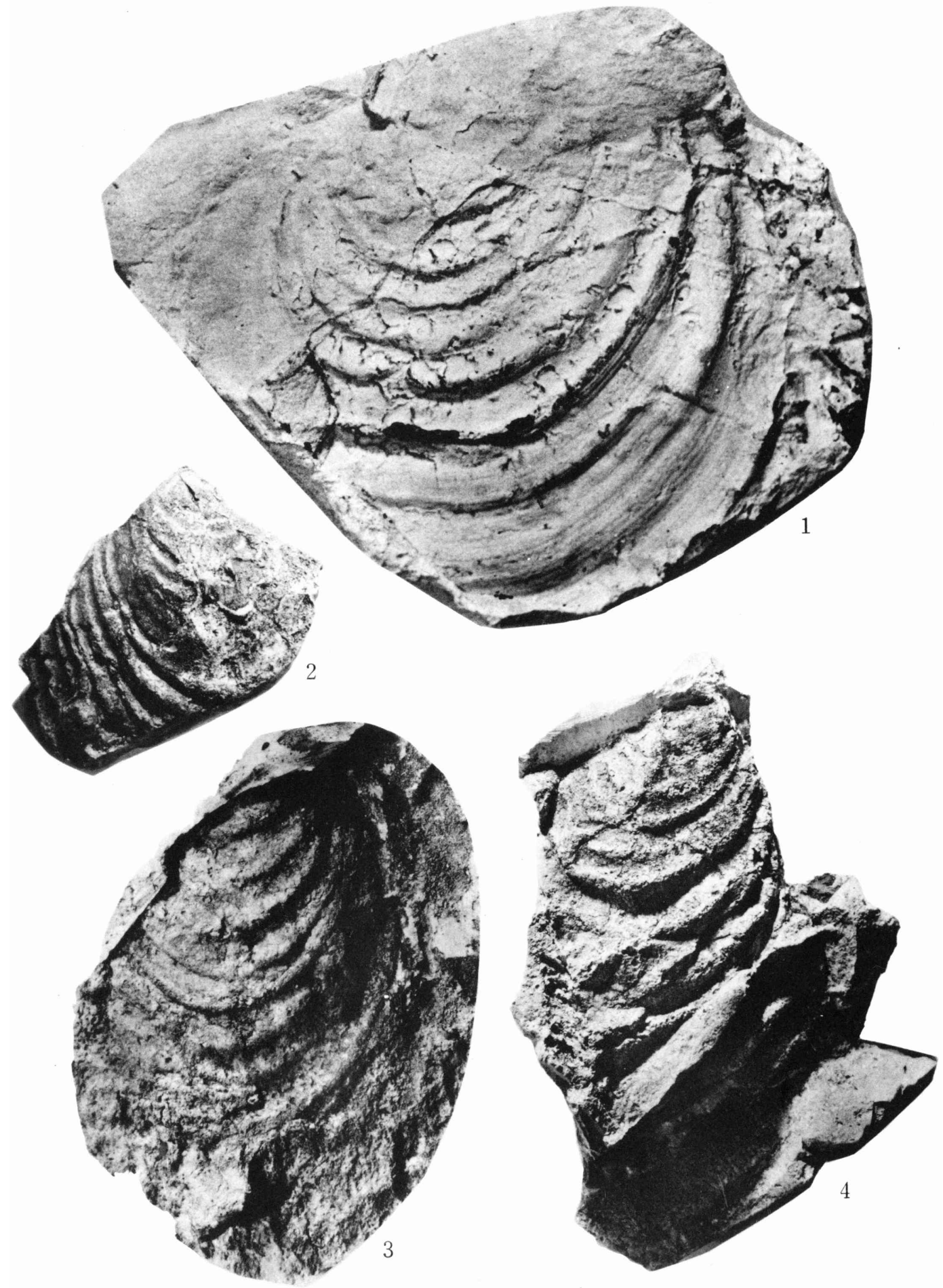

Y. TAkAi \& T. MAtsumoto: Cretaceous-Tertiary unconformity 
Plate 12 


\section{Explanation of Plate 12}

Fig. 1, 2. Inoceramus elegans pseudosulcatus NAGAo and MAтsumoto................ 275 KG 0101 (Fig. 1) and KG 0102 (Fig. 2) from loc. KG 01, unit IIIc Kita Takenoshima, Izumi-gun, Kagoshima Prefecture (Y. TAKAI Coll.), $\times 2$

Fig. 3. Inoceramus cf. balticus toyajoanus NAGAO and MAтsumoto .................. 274 KG 0302, from loc. KG 03, unit IIIc, Kita Takeno-shima, Izumi-gun, Kagoshima Prefecture (Y. TAKAI Coll.), natural size

Photos by Yasuaki TAKaI. 


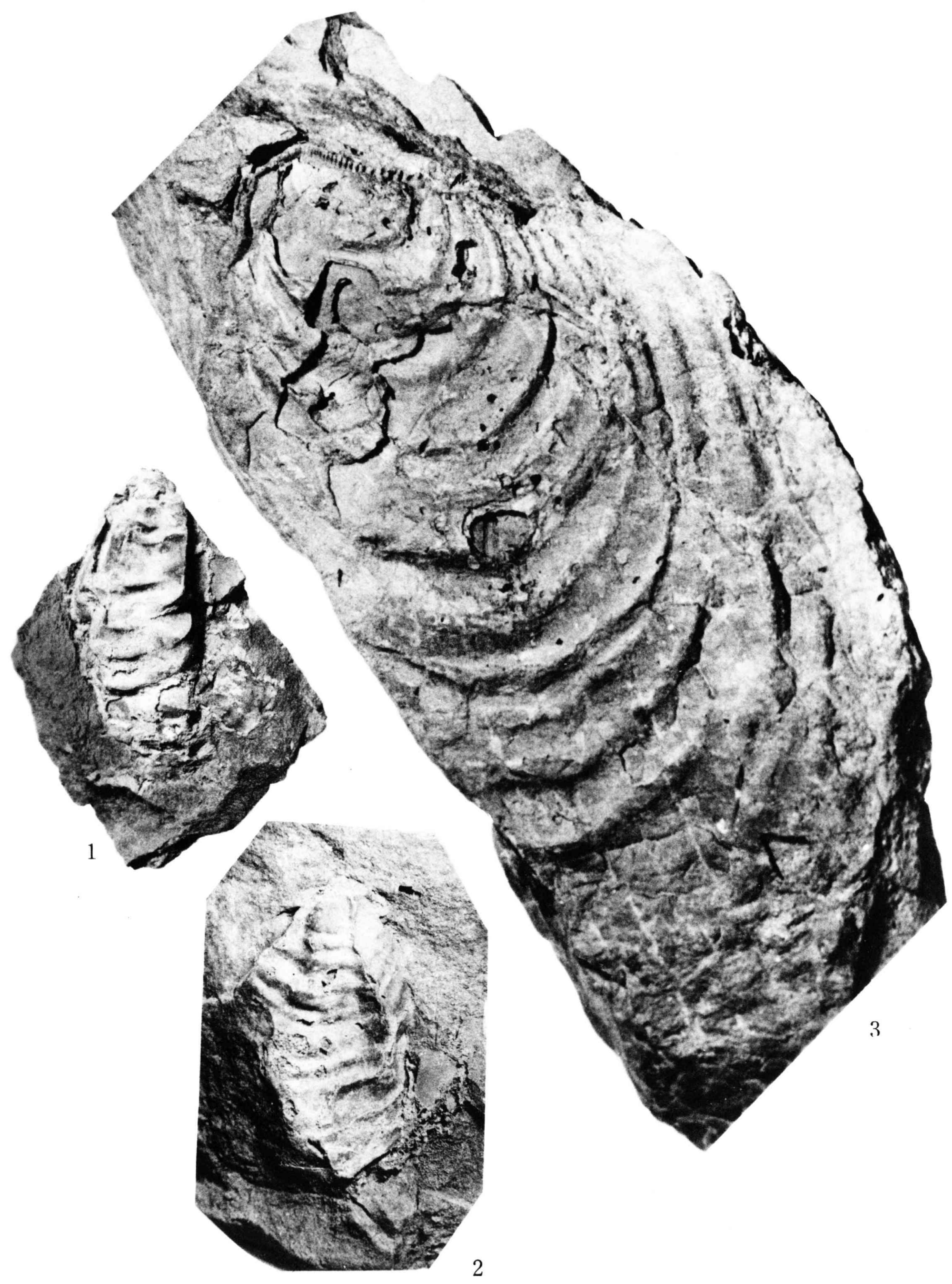

Y. Takai \& T. Matsumoto; Cretaceous-Tertiary unconformity 